\title{
EXCURSION TO TONBRIDGE AND TUNBRIDGE WELLS.
}

Saturday, Jung 28Th, 1879.

(Fourth of the Weald Series.)

\author{
Director一J. Logan Lobley, Esq., F.G.S. \\ (Report by William FawcetT, Esq., B.So.)
}

A large number of the Members of the Association met at Tonbridge to inspect the country from Tonbridge to Tunbridge Wells.

On the way to Sontbborough, Mr. Lobley pointed out the main features in the physical geology of the country, and the various strata to be met with. Tonbridge town is situated on the Alluvium formed by the Medway, the station is on the Tunbridge Wells Sand; and at the Hastings Road is first seen the Wadhurst Clay, which extends to Quarry Hill. The Ashdown Sand at Quarry Hill, thrown up by a fanlt, is interesting, as it is the lowest member of the Wealden group. A short distance after passing the Mabledon Lodge we again come npon the Wadhurst Clay, succeeded at the Penshurst road by the Tunbridge Wells Sand, which extends beyond Tunbridge Wells, with outliers here and there of the Weald Clay. At one of those points on the road from which a view may be had of the valley of the Medway, Professor Morris spoke of the difficult question of the origin of the Medway gravels. These gravels occur at various heights above the present bed of the river, up to as high as 300 feet. It is remarkable that in no part of the Weald are gravels found at any great distance from the margins of streams; and hence it is inferred that they have been laid down by rivers actually running in the same courses as at present. The gravels along the upper stream of the Medway consist only of Wealden pebbles, but, on the hanks of the Eden, the western tributary of the Medway, they also contain flints and Tertiary pebbles. The Eden joins the Medway at Penshurst; from that point, onwards, the gravels combine the characters of the upper Medway gravels and the Eden gravels, until the Medway has passed well out of the Weald country, and then the Wealden pebbles disappear. Again, the 
gravels of the Beult and Teise, the eastern tributaries, joining the Medway at Yalding, are composed of Wealden pebbles. Now when it is seen that the Upper Medway, the Beult, and Teise, and their feeders, drain Hastings Beds, and that the Eden runs down from the Chalk escarpment, it appears difficult to explain the composition of the gravels on any other hypothesis than that adopted by the Geological Survey, viz., that the gravels were formed by rivers running in the same courses, and (contrary to the theory of Mr. S. Wood, jun.) in the same divection as at present. One difficulty at first sight is that the Wealden pebbles disappear in gravels near the mouth of the Medway, but this is explained by saying that the débris of the Wealden Beds, either entirely disappear almost as soon as formed, as in the case of the calcareous " Rag," or are of a character so soft in comparison with flints and Tertiary pebbles, that they soon wear down from pebbles into sand. There appears, then, to be proof that rivers have excavated valleys to the depth of at least 300 feet. It is impossible to say how much more river erosion had taken place before these highest gravels were deposited, but if it was as much as 300 feet, that amount would account for the whole of the subsequent denudation of the original "plane of marine denudation"; that is to say, all the present configuration of the country, the hills and valleys, are due to the action only of rain and rivers. Certainly there is no evidence of any other agency; there are no raised beaches, the result of marine denudation, no drift left by tidal erosion, no moraines by glaciers.

At Southborough, lunch was provided at the Hand and Sceptre Hotel, and the arrangements made seem to have given general satisfaction. After a visit to Pennington Lane, which affords a grand view over the Medway valley and some of the richly-wooded lateral valleys, the party proceeded towards Tunbridge Wells.

On the way, Mr. Lobley pointed out an outlier of the Weald Clay at Mrs. Newnham's brickfields. Arriving by Mount Ephraim on the famous and beautiful Common, the higher valleys of the district were seen, and the summit of the Weald, Crowborough Beacon, at length bounded the view. The Tunbridge Wells Sand is conspicuously displayed in the picturesque "rocks" which stud the higher parts of the Common near Mount Ephraim. The sand is so well compacted that soft sandstone rock is the result, and, where it is harder than elsewhere, greater resistance to weathering 
has given outstanding masses, some most grotesque in form and appearance.

Permission was kindly given to visit the charming grounds of the Spa Hydropathic Establishment, which fronts Bishop's Down at the eastern extremity of the Common. In the grounds may be seen a good specimen of the beautiful little ralleys which abound in the neighbourhood, and which, with the fine timber adorning both hills and valleys, render this district so attractive.

A little further to the east the Tunbridge Wells Sand is again characteristically seen on Rusthall Common, where the rocks are still more striking than at Mount Ephraim. One of these masses has received the name of the "Toad Rock," from its resemblance to that animal, and others, too, are known by distinct names. They are fine examples of rocks of various degrees of hardness, acted upon by atmospheric agencies.

Leaving Rusthall Common, the party crossed the "Happy Valley," having Wadhurst Clay in the bottom, to the well-known "High Rocks," again showing Tunbridge Wells Sand, here thrown up by a fault. After inspecting these huge masses of soft sandstone, with their remarkable clefts, Members made their way by the narrow valley along which runs one of the feeders of the Medway, the boundary between Kent and Sussex, to Tunbridge Wells Station, for the return to London.

\section{ORDINARY MEETING.}

JULх 4тн, 1879.

Prof. T. Rupert Jones, F.R.S., F.G.S., President, in the Chair.

The Donations to the Library received since the previous meeting were announced, and the donors received the thanks of the Association.

The President having left the chair, it was taken by Prof. J. Morris, M.A., F.G.S., Vice-President, when 